\title{
Reformulation of Medical Rehabilitation against Victims of Narcotics Abuse in Indonesia
}

\author{
Jumriani Nawawi ${ }^{1}$, Slamet Sampurno ${ }^{2}$, M. Syukri Akub ${ }^{2}$, Nur Azisa ${ }^{3}$ \\ ${ }^{1}$ Lecturer at Institut Agama Islam Negeri Bone (IAIN) Bone, South Sulawesi, Indonesia, ${ }^{2}$ Professor, Department of \\ Criminal Law, Faculty of Law, Hasanuddin University, Indonesia, ${ }^{3}$ Associate Professor, Department of Criminal \\ Law, Faculty of Law, Hasanuddin University, Indonesia
}

\begin{abstract}
The criminal sanction that occurred against the perpetrators of narcotic users is still inclined to apply imprisonment rather than rehabilitation measures. The research is a normative legal research using a statute, case, and conceptual approaches. The results show that The essence of medical rehabilitation sanctions imposing against victims of narcotics abusers who adhere to the double track system which is oriented to criminal and action sanction. Rehabilitation of narcotics abusers and addicts the purpose to cure the narcotics dependence against abusers and addicts so that the abusers and addicts recover from narcotics. In order to realize a narcotics-free State, the implementation of medical rehabilitation sanction imposing must reflect philosophical, juridical and sociological values while considers the legal development and needs of the community in implementing narcotics crime eradication.
\end{abstract}

Keywords: Drugs;Narcotics; Rehabilitation; Victims.

\section{Introduction}

Indonesia affirms firmly through its commitment to combat narcotics abuse and illicit trafficking, various specific regulations regarding narcotics in the form of laws have been made with the aim of combating narcotic crimes. ${ }^{1}$ Although narcotics are substances or drugs that come from plants or not plants, synthetic and semi-synthetic that can cause a decrease and change of consciousness, loss of pain and can cause dependence. ${ }^{2}$ On the one hand, the availability of narcotics is a useful drug in the field of medicine or health services and the development of science, but on the other hand it creates a very detrimental dependency if it is misused.To prevent and eradicate the misuse and illicit trafficking of narcotics that have been detrimental to and endanger the lives of the people, the assertion of the need for crime prevention is integrated with the overall social policy and national development planning. ${ }^{3}$

The role of rehabilitation in healing addictions for narcotics addicts is very important, because of the increasing number of narcotics addicts. ${ }^{4}$ The effectiveness of rehabilitation to cure victims of narcotics is very necessary, given the difficulty of victims or users of narcotics to be separated from narcotics addiction individually. In rehabilitating drug addicts, the National Narcotics Agency cooperates with various parties includes foundations, hospitals and health centers. The addicts are rehabilitated so they can be free from the snare of drugs and return to normal life. Rehabilitation is important to do because the abuse of narcotics will have a negative impact on health, such as HIV-AIDS, hepatitis, infections, heart disease, blood vessel disorders in pregnancy and other health problems to death.

Based on previous research, it was found that neighboring country, Malaysia had first placed its citizens categorized as drug users as victims and no longer as perpetrators of crime. In Malaysia, drug users or addicts receive verdicts for rehabilitation even with a maximum limit of 3 times. Another example is Portugal, the country has decided that drug addicts who are intended as drug owners for their own use remain prohibited, but violations of this rule will be considered administrative violations, and no longer considered crimes. From various writings, it is known that in these two countries, there was then a decrease in the number of drug users, a decrease in mortality due to drug use 
and a decrease in HIV-AIDS cases. This is precisely the case with Indonesia, where each year there is an increase in the number of drug use, the overload of correctional facilities with prisoners related to drug use. ${ }^{5}$

Protection of narcotics addicts and abusers is achieved with the promulgation of Act No. 35 of 2009 concerning Narcotics. The Narcotics Act adheres to the Double Track System, which is a criminal law policy in the formulation of the provisions governing sanctions given to narcotics abuse offenders, namely in the form of criminal sanctions and sanctions for acts considering that narcotics abusers have a slightly different position from other. One side of the narcotics user is a criminal offender who must be punished, but on the other hand is a victim of a criminal offense he committed himself, so an action in the form of rehabilitation is necessary. ${ }^{6}$

The National Narcotics Agency of South Sulawesi Province noted the number of drug users and illegal drugs in South Sulawesi are still quite high. So that with rehabilitation as an effort or the best way to save people from the drugs. ${ }^{7}$ Rehabilitation of narcotics addicts is also a form of social protection that integrates narcotics addicts in a social order so that no longer commits drug abuse. However, as it turns out into practice, rehabilitation of abusers is considered unsuccessful. ${ }^{8}$ Many cases of narcotics abuse experienced by Indonesian public figures are an example of the ineffectiveness of rehabilitation as one of the ways implemented in combating narcotics crimes. Where in some cases, the public figures that were decided by the judge undergoing rehabilitation even reused. As if rehabilitation is only to stop the abuse of narcotics for a while and still less able to treat and make peoples to free from narcotics addiction.

In addition, because not a few of the abusers who are caught must lose their right to undergo rehabilitation as they should so the right to obtain access to essential health is not obtained especially for drug addicts, because the addict will be sentenced to prison. While it is common knowledge that prison is no longer a safe place from these illicit goods. Hence, rehabilitation sanctions should be premium remidium and imprisonment as ultimumremidium in the prevention and eradication of narcotics crime so that the narcotics circle can be broken down to its roots.

\section{Method}

The research is a normative legal research using a statute, case, and conceptual approaches. ${ }^{9}$ The research location was centered on the National Narcotics Agency of South Sulawesi Province and the District Narcotics Agency. In this research, we uses direct interviews with narcotics abusers, the parties to the National Narcotics Agency, the parties to the Provincial National Narcotics Agency and the rehabilitation institutions.

The Essence of Medical Rehabilitation Sanction Imposing against Narcotics Abuse Victims: At this time, inevitably that the development of narcotics use is increasing rapidly and not for medicinal purposes or scientific development, but to gain large profits, namely by conducting illegal drug trafficking in various countries. ${ }^{10}$ This raises concern for the international community, given the impact caused by the misuse of narcotics which is very dangerous for the life of the nation and country, especially for the continued growth and development of the younger generation. Based on these considerations, several international conventions have been issued to deal with the development of the illegal narcotics trade.

Prevention of narcotics abuse is intended to fortify the public so as not to get involved in narcotics abuse, the target is people who have never been involved with narcotics abuse so as not to become abusers and not to become dealers. ${ }^{11}$ Rehabilitation of narcotics abusers and addicts to cures the conditions of narcotics dependence against abusers and addicts so that the abusers and addicts recover from addiction/narcotics dependence. Abusers are prohibited and threatened with prison sentences as well as narcotics addicts who do not report themselves to recover are also threatened with criminal penalties, but forced efforts and punishment in the form of rehabilitation.

The phase of assessment at the Institution of Compulsory Reporting as described in the table is a phase that is general in nature and applies to all addicts and victims of narcotics abusers. This stage is also in accordance with what is regulated in Government Regulation No. 25 of 2011 concerning the implementation of the Compulsory Reporting on Narcotics Addicts. According to the author, this phase is still incomplete if it only reaches the rehabilitation phase. It is better to avoid the relapse of addicts and victims of narcotics abusers that there must be progress monitoring after following the rehabilitation phase to monitor the situation of the former addict. As for the number of addicts and victims of narcotics abuse that run the compulsory reporting at the research location, can be seen in Chart 1 . 


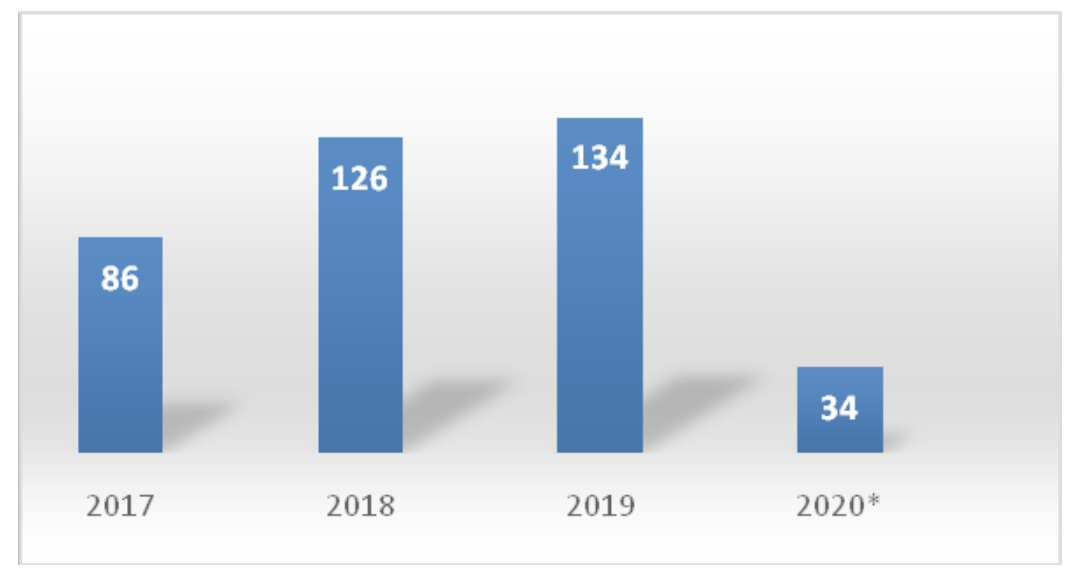

Source: Primary data, edited (March 16, 2020).

\section{Chart 1. Number of addicts and victims of narcotics abuse to compulsory reporting at BNNK Watampone, South Sulawesi, Indonesia. ("Updates for January - March)}

Based on the result of interview with Mrs. Eni as the Division Head of Rehabilitation of BNNK Bone as place to receive the compulsory reporting, as the result of reporting, it will be processed by conducting an assessment to determine the condition of the addict. Accordingly, the intended assessment includes:

a. Interview is to find out the medical history of addicts, the extent of narcotics use, the psychological state, the social background and to explore whether there is involvement with the network.

b. Observation is to see the behavior of addicts, whether there are things that are hidden.

c. Physical examination is to find out the vital signs in the body of an addict.

As result of assessment can be seen whether the addict has a connection with the network. If an indication of involvement with the network is found then this will be a reference for the Sub-Section of BNNK Bone for immediate action. Regarding the identity of the addict who is obliged to report will be guaranteed confidentiality. As a consequence, if not obey the rule of this compulsory reporting, the parents or guardians will be threatened with imprisonment as stipulated further in Article 128 of Act No. 35 of 2009 concerning narcotics.

Based on the narcotics laws, narcotics users can be seen from 2 (two) points of view. The first is the use of narcotics legally or in accordance with applicable legal requirements. The second is the use of narcotics illegally or contrary to the law referred to as narcotics abuse. Narcotics can be used legally and not against the law if it is done for medical purposes and scientific development. The Narcotics law also has two approaches to those who use narcotics illegally or against the law, or in other words misuse narcotics.

The first approach is to see narcotics users as victims so that they must be rehabilitated and the second is to see narcotic users as criminals. As in the explanation section of the narcotics law, it also regulates criminal sanctions for the abuse of narcotics precursors for narcotics manufacturing. To create a deterrent effect on the perpetrators of narcotics abuse and illicit trafficking of narcotics precursors, it is regulated regarding the imposition of criminal sanctions, both in the form of special minimum penalties, 20 (twenty years) imprisonment, life imprisonment, and capital punishment based on the group, type, size, and number of narcotics.

The policy in combating criminal acts of narcotics abuse is a positive legal policy which in essence is not merely the implementation of normative juridical laws. Besides the normative juridical approach, criminal law policy also requires a comprehensive and integral factual juridical approach. The law has provided sufficient legal umbrella and has regulated everything from suppliers, importers or producers to users, but at the level of implementation of law enforcement efforts still need to be improved. This is related to the performance of the legal apparatus itself.

The policy of crime eradication through the making of criminal law is an integral part of the community 
protection policy and is an integral part of social politics. Social politics can be interpreted as all rational efforts to achieve the welfare of society and at the same time include community protection. One function of the imposition of rehabilitation sanctions is to carry out extra countermeasures against the problem of narcotics abuse which resolves the problem from its roots, namely from abusers in this case is abusers for themselves, addicts and victims of narcotics abuse.

\section{Legal reform on Medical Rehabilitation against} Narcotics Abuse: Legal renewal is defined as a process of conducting review on various formulations of applicable laws and regulations, and to which are implemented a number of changes in order to achieve efficiency, fairness and also the opportunity to obtain justice according to applicable law. It is generally understood that the actual legal reform takes place, when the body of authority forms the law, namely the judiciary and the legislators, the government and the legislative authority in power or authority in a country take a number of steps (legal policy) which is required to test the applicable law. ${ }^{12}$ The legal policy was made in the context of legal reform.

The criminal justice system is a system in a society to overcoming the problem of crime. This system is considered successful if the majority of public reports as crime victims can be resolved by bringing the perpetrators to court and convicted. ${ }^{13}$ The components that work together in the system of sanctions imposing against victims of narcotics abusers are the police, prosecutors, courts, prisons, the National Narcotic Agency. The four components are expected to work together to form what is known as the "integrated criminal justice system".

Hence, to be able to guarantee abusers as perpetrators of narcotics misuse in accordance with the purpose of making the Act, the Narcotics Act contains or adheres to the rehabilitation justice system in addition to criminal justice. Therefore, the Narcotics Law adheres to the Double Track Criminal System. The dealer follows the criminal justice track while the abuser follows the rehabilitation justice track. The rehabilitation justice system is a judicial system in which sanctions out of criminal sanctions become rehabilitation sanctions with the purpose that the suspect is cured and does not become a further abuser. ${ }^{14}$

The justice system that has been in effect mostly focuses only on the criminal justice system. Where, the abusers are victims and not free from prison sentences. From those who undergone prison sentences, not a few are returning to abuse narcotics (relapse). As well with those who undergo rehabilitation either through legal step or compulsory reporting, not a few who return to abuse narcotics (relapse). For this reason, according to the author, the imposition of sanctions that have been there needs to be reformulated again, where in the narcotics justice system that has been adhering to a dual track system independently between criminal and rehabilitation can be cumulative. In the sense that the imposition of sanctions against abusers is given a double sanction namely rehabilitation and prison sanction altogether. Rehabilitation sanction were imposed by considering the position of the abuser as a victim who should have received special treatment (medical) in order to be able to eliminate detox which could trigger the return of relapse.

For this reason, there are several articles in Act No. 35 of 2009 concerning narcotics which should be reformulated so that it can be imposed on abusers so that the purpose of this law can be achieved optimally, such as the narcotics addicts and victims of narcotics abuse must undergo medical and social rehabilitation, this article only allows imposed on those who are addicted and those who are persuaded, tricked, deceived, forced and threatened with using narcotics. While, many of abusers who first used narcotics because they were persuaded and deceived, because it is difficult to prove that Article 54 cannot be imposed on him as a victim.

\section{Conclusion}

The essence of medical rehabilitation sanctions imposing against victims of narcotics abusers who adhere to the double track system which is oriented to criminal and action sanction. In order to realize a narcotics-free State, the implementation of medical rehabilitation sanction imposing must reflect philosophical, juridical and sociological values, while considers the legal development and needs of the community in implementing narcotics crime eradication. The ideal concept of medical rehabilitation sanctions imposing against on victims of narcotics abuse can be done by reformulating several articles in Act No. 35 of 2009 concerning Narcotics which should be reformulated so that it can be imposed on abusers so that the purpose of this law can be achieved optimally.

Ethical Clearance: No ethical approval is needed. 


\section{Source of Funding: Self}

\section{Conflict of Interest: Nil}

\section{References}

1. Fellner, J. Race, drugs, and law enforcement in the United States. Stanford Law and Policy Review, 2009;20 (1) 257-264.

2. Lisa, J., and Sutrisna, N. Narkoba, Psikotropika, dan Gangguan Jiwa (Tinjauan Kesehatan dan Hukum). NuhaMedika. Yogyakarta, 2019;4.

3. Arif, B.N. Bunga Rampai Kebijakan Hukum Pidana. Semarang. Kencana, 2010;6.

4. Ariyanti, V. Indonesia's criminal law policy on the victim of narcotics abuse in the perspective of victimology. Veteran Law Review, 2018; 1(1), 3249.

5. Triadi, R. Level of compliance of narcotics victims in turning medical and social rehabilitation. Journal of Islamicate Studies, 2018; 1(2): 23-41

6. Febriana, M., Soewondo, S. S., Hamid, M. A., \& Heryani, W. Legal Protection of Narcotic Abusers: A Restorative Justice Perspective. J. LPol'y \& Globalization, 2019; 88 (1) 64.

7. Tribun News. Available online at: http://makassar. tribunnews.com/2018/11/16/bnn-sulsel-jikakecanduan-narkoba-jangan-malu-dan-takut- melapor-ke-bnn-anda-tidak-akan-dipenjara, accessed on 17 November 2018

8. Liputan 6 News. Available online at: https://www. liputan6.com/news/read/3391765/bnn-pecanduyang-kembali-konsumsi-narkoba-usai-rehabilitasi70-persen, accessed on 23 November 2018

9. Fajar, M., and Ahmad, Y. DualismePenelitian Hukum Normatif dan Empiris. Pustaka Pelajar. Yogyakarta, 2017; 34

10. Adi, K. Diversi Tindak Pidana Narkotika Anak. Malang: Setara Press, 2015; 31

11. Iskandar, A. Penegakan Hukum Narkotika (Rehabilitatif Terhadap Penyalah Guna Dan Pecandu Represif Terhadap Pengedar). Jakarta: PT Elex Media Komputindo. 2019; 7

12. Prasetyo, T. Pembaharuan Hukum Perspektif Teori Keadilan Bermartabat. Malang: Setara Press, 2017; 26.

13. Reksodiputro. M. Sistem Peradilan Pidana Indonesia (Peran Penegak Hukum Melawan Kejahatan). Jakarta: Pusat Pelayanan Keadilan dan Pengabdian Hukum. 1997; 84.

14. Idaiani, S. Relapse in Drugs, Psychotropic, Addictive Abuse Post Rehabilitation: "Policy and Prevention Programs". 4th International Symposium on Health Research, 2019; 56-59. 